\title{
Evolution of our understanding of myeloid regulatory cells: from MDSCs to Mregs
}

\author{
Masoud H. Manjili ${ }^{1,2}$ *, Xiang-Yang Wang ${ }^{2,3}$ and Scott Abrams ${ }^{4}$ \\ ' Department of Microbiology and Immunology, Virginia Commonwealth University, Richmond, VA, USA \\ ${ }^{2}$ Massey Cancer Center, Virginia Commonwealth University, Richmond, VA, USA \\ ${ }^{3}$ Department of Human and Molecular Genetics, Virginia Commonwealth University, Richmond, VA, USA \\ ${ }^{4}$ Roswell Park Cancer Institute, Buffalo, NY, USA
}

\section{Edited by:}

Amir Sharabi, Tel-Aviv University, Israel

Reviewed by:

Norberto Walter Zwirner, Institute of Biology and Experimental Medicine, Argentina

Franca Ronchese, Malaghan Institute of Medical Research, New Zealand

*Correspondence:

Masoud H. Manjili, Microbiology and Immunology, Virginia Commonwealth University, Massey Cancer Center, Box 980035, 401 College Street,

Richmond, VA 23298, USA

e-mail:mmanjili@vcu.edu
The term myeloid-derived suppressor cells (MDSCs) was first suggested in 2007 in order to reflect the origin and function of myeloid cells during immunosuppression in cancer and other pathologic conditions. Emerging evidence suggests that MDSCs suppress CTL and Th1 responses in malignant diseases while they regulate effective immune responses in parasitic and helminth infections as well as Th17 inflammatory response during autoimmune diseases. Based on these data, the term myeloid regulatory cells (Mregs) more accurately reflects their function and interactions with different cells of the immune system during diseased conditions. Here, we provide evidence on the multifaceted function of Mregs during diseased states.

\section{Keywords: myeloid-derived suppressor cells, myeloid regulatory cells, Nippostrongylus, Leishmania, helminths,} immunotherapy of cancer

\section{MREGS OPERATE AS MDSCS FOR THE SUPPRESSION OF ANTI-TUMOR IMMUNE RESPONSES}

Myeloid-derived suppressor cells (MDSCs) were originally described as immunosuppressive cells of myeloid origin. These cells are known to be a heterogeneous mixture of myeloid cells at different stages of differentiation. They were initially named "immature myeloid cells" or "myeloid suppressor cells" (MSC) until they matured into MDSCs in 2007 (1). Most of the attention was initially focused on the role of these cells in cancer, because tumor-derived factors were shown to facilitate the production of MDSCs as well as their accumulation in the secondary lymphoid tissues and at the tumor site. In mice, MDSCs are broadly defined by the expression of CD11b and Gr-1, and could be subdivided into monocytic $\left(\mathrm{CD} 11 \mathrm{~b}^{+} \mathrm{Ly} 6 \mathrm{C}^{\text {hi }} \mathrm{Ly} 6 \mathrm{G}^{-}\right)$and granulocytic

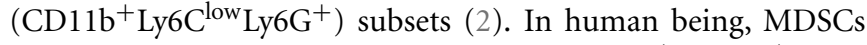
are characterized by the expression of $\mathrm{CD}_{3} 3^{+} \mathrm{CD} 11 \mathrm{~b}^{+} \mathrm{HLA}$ $\mathrm{DR}^{-/ \text {low }}$. Human MDSCs are classified into monocytic and granulocytic subsets based on $\mathrm{Lin}^{-} \mathrm{CD} 11 \mathrm{~b}^{+} \mathrm{CD} 14^{+} \mathrm{CD} 15^{-}$and $\mathrm{Lin}^{-} \mathrm{CD} 11 \mathrm{~b}^{+} \mathrm{CD} 14^{-} \mathrm{CD} 15^{+}$, respectively (3). In fact, MDSCs reflect a mechanism by which myeloid regulatory cells (Mregs) suppress the host's anti-tumor immune responses in favor of the tumor.

The ability of MDSCs to suppress anti-tumor Th1 and CTL immune responses has been demonstrated by their direct and indirect impacts on the immune system. The direct immune suppressive function of MDSCs is accomplished through at least three different pathways which include contact-dependent and/or contact-independent suppression of effector T cells (48), induction of Tregs (9), and inhibition of T cell trafficking (10). Contact-dependent suppression of T cells by MDSCs causes nitration of tyrosine residues in the TcR-CD8 complex, thereby disrupting the tumor antigen-MHC class I recognition by the
TcR (4). Suppression of T cell proliferation during stimulation with anti-CD3/CD28 antibodies was also shown to be due to a contact-dependent mechanism (5). Cell contact is also required for MDSC-mediated suppression of NK cells in patients with hepatocellular carcinoma (6). It was reported that membranebound TGF- $\beta 1$ on MDSCs is responsible for MDSC-mediated suppression of NK cell cytotoxicity, NKG2D expression, and IFN- $\gamma$ production (11). Recently, it was reported that granulocytic MDSC subset can negatively regulate NK cell activation and function in response to vaccinia virus infection via producing reactive oxygen species (12). Most groups have found contact-independent mechanisms of T cell suppression by MDSCs releasing soluble factors such as IDO, arginase-1, nitric oxide, reactive oxygen species, and peroxynitrites $(13,14)$. MDSCs also produce IL-10 and TGF- $\beta$, resulting in the induction of Tregs in an antigen-specific manner (15). Finally, MDSCs can downregulate the expression of CD62L, which is an important receptor for $\mathrm{T}$ cell homing to the lymph nodes. This is accomplished by the expression of a disintegrin and metalloproteinase (ADAM)-17 on MDSCs which cleaves and results in shedding of the ectodomain of CD62L (10).

Indirect mechanisms of T cell suppression by MDSCs, which are mediated by granulocytic subset, include expression of matrix metalloproteinases (MMPs). MMPs can support the bioavailability of VEGF, thereby acting as tumor angiogenic factors; MMPs can also help to break down the extracellular matrix, facilitating dissemination and metastasis of the tumor (16).

\section{MREGS MODULATE Th1 RESPONSE AND SUPPORT Th2 RESPONSE: PROTECTIVE IMMUNE RESPONSES AGAINST PARASITIC AND HELMINTH INFECTIONS}

While Mregs are harmful to anti-tumor immunity and some other diseases in which a robust Th1 response or CTL response 


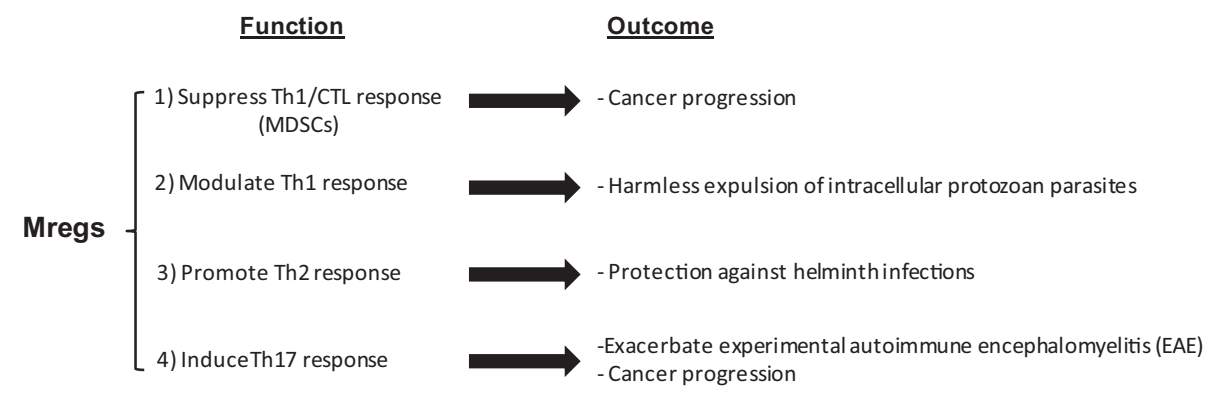

FIGURE 1 |The multifaceted function of Mregs.

is required, the ability of the Mregs to limit and modulate Th1 responses or support a skewed Th2 immunity could be beneficial during parasitic and helminth infections. The Th1 modulatory function of Mregs is evident during infection with intracellular protozoan parasites such as Leishmania and Trypanosoma, expulsion of which typically requires a controlled Th1 immunity to prevent the host tissue damage. In fact, the acute immune response to protozoan infection is associated with a strong IFN- $\gamma$ producing Th1 response (17) associated with the expansion of MDSCs. For instance, in Trypanosoma cruzi infection, expansion of MDSCs is regulated by the induction of IFN $-\gamma$ producing Th1 cells (18). In Leishmania major infection, IL12-induced IFN- $\gamma$ production by Th1 cells promotes resistance to infection and facilitates the expansion of MDSCs (19); MDSCs could also kill the intracellular parasite L. major in a NO-dependent manner (20). Although Th1 response plays a critical role against these infections, excessive Th1 response could be detrimental to the host. Thus, MDSCs modulate Thl inflammatory response in order to protect the host from tissue damage. Consequently, during T. cruzi infection, depletion of MDSCs results in an excessive production of IL- 6 and IFN- $\gamma$, an elevated Th17 response, leading to mortality of the host (21). Similar observations were made in Toxoplasma gondii infection, in which an antiparasite Th1 inflammatory response results in extensive intestinal necrosis in the absence of monocytic MDSCs (22).

Host-protective immunity against helminth infections involves a skewed Th2 response associated with elevated levels of MDSCs, as shown during infection with Schistosoma mansoni (23, 24), Taenia crassiceps (25), Nippostrongylus brasiliensis (26), and Brugia malayi (27). In fact, MDSCs support a skewed Th2 response by the helminth antigens such as glycans that act as Th2 adjuvants (28). Very recently, it was demonstrated that adoptive transfer of monocytic $\left(\mathrm{CD} 11 \mathrm{~b}^{+} \mathrm{Ly} 6 \mathrm{C}^{\text {hi }} \mathrm{Ly}_{6 \mathrm{G}^{-}}\right)$MDSCs, strong suppressors of Th1 responses, failed to protect $N$. brasiliensis-infected mice, whereas granulocytic MDSCs were found to be protective (29). This immunoregulatory role of MDSCs was shown to be mediated by mast cell-derived histamine (30).

\section{MREGS DIRECTLY INDUCE HOST-PROTECTIVE Th17 IMMUNE RESPONSES}

Immunoregulatory functions of Mregs on Th17 differentiation and inflammatory responses have been reported in experimental autoimmune encephalomyelitis (EAE). We showed that the progression of EAE in mice was accompanied by a profound expansion of $\mathrm{CD} 11 \mathrm{~b}^{+} \mathrm{Gr}-1^{+}$MDSCs, which resembled tumor-expanded MDSCs, phenotypically and functionally (31). However, EAE-associated Mregs were found to be highly efficient in producing IL-1 $\beta$, thereby promoting the differentiation of naive $\mathrm{CD} 4^{+} \mathrm{T}$ cells into Th17 cells. Depletion of Mregs using gemcitabine markedly reduced the severity of EAE as well as Th17 cells and the inflammatory cytokines IL-17A and IL- $1 \beta$ in the lymphoid tissues and spinal cord (31). The pathogenic activities of CCR2 ${ }^{+}$Ly6C $^{\text {hi }}$ or CD11b ${ }^{+}$Ly6C $C^{\text {hi }}$ cells, likely due to monocytic Mregs, have also been reported by other studies $(32,33)$.

Intriguingly, the ability of Mregs to induce Th17 differentiation has also been shown in tumor-bearing mice (34) and patients with ovarian cancer (34). Development of Th17 cells from naive-, memory-, or tumor-infiltrating CD4+ $\mathrm{T}$ cells was shown to be driven by Mregs that produce IL-1 $1 / \mathrm{IL}-6 / \mathrm{IL}-23 / \mathrm{NO}$ (34). Indeed, recent studies also support a positive correlation between Mregs levels and the levels of Th17 cells or IL-17 production in patients with esophageal cancer (35) or gastrointestinal cancer (36). These new findings not only unmask the different aspects of Mreg functions in the regulation of Th17 cells other than Th1 or Th2 cells, but also highlight the proinflammatory effects of these cells. It is unclear whether the immunosuppressive and proinflammatory activities of Mregs can be uncoupled. However, the proinflammatory feature of these cells may represent a pathogenic factor given the intimate link between inflammation and tumorigenesis, and the progression of inflammatory autoimmune diseases. Although the therapeutic benefits of targeting Mregs in autoimmune disorders remain to be clarified, these studies provide evidence supporting the pleiotropic regulatory effects of Mregs in different contexts.

The multifaceted function of myeloid cells in the exacerbation and amelioration of different diseases associated with the suppression or induction of specific types of the immune response suggests that the term Mregs can better explain their function (Figure 1). In addition, controversial reports on the role of these cells in autoimmune diseases can be consolidated and understood in the context of their regulatory function under certain conditions, which is not merely limited to their immune suppressive function.

\section{REFERENCES}

1. Gabrilovich DI, Bronte V, Chen SH, Colombo MP, Ochoa A, Ostrand-Rosenberg $\mathrm{S}$, et al. The terminology issue for myeloid-derived suppressor cells. Cancer Res (2007) 67(1):425. doi:10.1158/0008-5472.CAN-06-3037

2. Movahedi K, Guilliams M, Van den Bossche J, Van den Bergh R, Gysemans $\mathrm{C}$, Beschin A, et al. Identification of discrete tumor-induced myeloid-derived 
suppressor cell subpopulations with distinct $\mathrm{T}$ cell-suppressive activity. Blood (2008) 111(8):4233-44. doi:10.1182/blood-2007-07-099226

3. Gros A, Turcotte S, Wunderlich JR, Ahmadzadeh M, Dudley ME, Rosenberg SA. Myeloid cells obtained from the blood but not from the tumor can suppress T-cell proliferation in patients with melanoma. Clin Cancer Res (2012) 18(19):5212-23. doi:10.1158/1078-0432.CCR-12-1108

4. Nagaraj S, Gupta K, Pisarev V, Kinarsky L, Sherman S, Kang L, et al. Altered recognition of antigen is a mechanism of $\mathrm{CD} 8+\mathrm{T}$ cell tolerance in cancer. Nat Med (2007) 13(7):828-35. doi:10.1038/nm1609

5. Morales JK, Kmieciak M, Graham L, Feldmesser M, Bear HD, Manjili MH. Adoptive transfer of HER2/neu-specific T cells expanded with alternating gamma chain cytokines mediate tumor regression when combined with the depletion of myeloid-derived suppressor cells. Cancer Immunol Immunother (2009) 58(6):941-53. doi:10.1007/s00262-008-0609-z

6. Hoechst B, Voigtlaender T, Ormandy L, Gamrekelashvili J, Zhao F, Wedemeyer $\mathrm{H}$, et al. Myeloid derived suppressor cells inhibit natural killer cells in patients with hepatocellular carcinoma via the NKp30 receptor. Hepatology (2009) 50(3):799-807. doi:10.1002/hep.23054

7. Rodriguez PC, Hernandez CP, Quiceno D, Dubinett SM, Zabaleta J, Ochoa JB, et al. Arginase I in myeloid suppressor cells is induced by COX-2 in lung carcinoma. J Exp Med (2005) 202(7):931-9. doi:10.1084/jem.20050715

8. Serafini P, Borrello I, Bronte V. Myeloid suppressor cells in cancer: recruitment, phenotype, properties, and mechanisms of immune suppression. Semin Cancer Biol (2006) 16(1):53-65. doi:10.1016/j.semcancer.2005.07.005

9. Serafini P, Mgebroff S, Noonan K, Borrello I. Myeloid-derived suppressor cells promote cross-tolerance in B-cell lymphoma by expanding regulatory $\mathrm{T}$ cells. Cancer Res (2008) 68(13):5439-49. doi:10.1158/0008-5472.CAN-07-6621

10. Hanson EM, Clements VK, Sinha P, Ilkovitch D, Ostrand-Rosenberg S. Myeloid-derived suppressor cells down-regulate L-selectin expression on CD4+ and CD8+ T cells. J Immunol (2009) 183(2):937-44. doi:10.4049/jimmunol. 0804253

11. Li H, Han Y, Guo Q, Zhang M, Cao X. Cancer-expanded myeloid-derived suppressor cells induce anergy of NK cells through membrane-bound TGF-beta 1. J Immunol (2009) 182(1):240-9. doi:10.4049/jimmunol.182.1.240

12. Fortin C, Huang X, Yang Y. NK cell response to vaccinia virus is regulated by myeloid-derived suppressor cells. J Immunol (2012) 189(4):1843-9. doi:10.4049/jimmunol.1200584

13. Yu J, Du W, Yan F, Wang Y, Li H, Cao S, et al. Myeloid-derived suppressor cells suppress antitumor immune responses through IDO expression and correlate with lymph node metastasis in patients with breast cancer. J Immunol (2013) 190(7):3783-97. doi:10.4049/jimmunol.1201449

14. Smith C, Chang MY, Parker KH, Beury DW, DuHadaway JB, Flick HE, et al. IDO is a nodal pathogenic driver of lung cancer and metastasis development. Cancer Discov (2012) 2(8):722-35. doi:10.1158/2159-8290.CD-12-0014

15. Huang B, Pan PY, Li Q, Sato AI, Levy DE, Bromberg J, et al. Gr- $1^{+} \mathrm{CD} 115^{+}$ immature myeloid suppressor cells mediate the development of tumor-induced $\mathrm{T}$ regulatory cells and T-cell anergy in tumor-bearing host. Cancer Res (2006) 66:1123-31. doi:10.1158/0008-5472.CAN-05-1299

16. Yang L, DeBusk LM, Fukuda K, Fingleton B, Green-Jarvis B, Shyr Y, et al. Expansion of myeloid immune suppressor $\mathrm{Gr}+\mathrm{CD} 11 \mathrm{~b}+$ cells in tumor-bearing host directly promotes tumor angiogenesis. Cancer Cell (2004) 6(4):409-21. doi:10.1016/j.ccr.2004.08.031

17. Egan CE, Sukhumavasi W, Butcher BA, Denkers EY. Functional aspects of Tolllike receptor/MyD88 signalling during protozoan infection: focus on Toxoplasma gondii. Clin Exp Immunol (2009) 156(1):17-24. doi:10.1111/j.1365-2249.2009. 03876.x

18. Goñi O, Alcaide P, Fresno M. Immunosuppression during acute Trypanosoma cruzi infection: involvement of Ly6G $(\mathrm{Gr} 1(+)) \mathrm{CD} 11 \mathrm{~b}(+)$ immature myeloid suppressor cells. Int Immunol (2012) 14(10):1125-34. doi:10.1093/intimm/ dxf076

19. Alexander J, Bryson K. T helper (h)1/Th2 and Leishmania: paradox rather than paradigm. Immunol Lett (2005) 99(1):17-23. doi:10.1016/j.imlet.2005.01.009

20. Pereira WF, Ribeiro-Gomes FL, Guillermo LV, Vellozo NS, Montalvão F, Dosreis GA, et al. Myeloid-derived suppressor cells help protective immunity to Leishmania major infection despite suppressed T cell responses. J Leukoc Biol (2011) 90(6):1191-7. doi:10.1189/jlb.1110608

21. Arocena AR, Onofrio LI, Pellegrini AV, Carrera Silva AE, Paroli A, Cano RC, et al. Myeloid-derived suppressor cells are key players in the resolution of inflammation during a model of acute infection. Eur J Immunol (2014) 44(1):184-94. doi:10.1002/eji.201343606
22. Dunay IR, Damatta RA, Fux B, Presti R, Greco S, Colonna M, et al. Grl(+) inflammatory monocytes are required for mucosal resistance to the pathogen Toxoplasma gondii. Immunity (2008) 29(2):306-17. doi:10.1016/j.immuni.2008. 05.019

23. Van Ginderachter JA, Beschin A, De Baetselier P, Raes G. Myeloid-derived suppressor cells in parasitic infections. Eur J Immunol (2010) 40(11):2976-85. doi:10.1002/eji.201040911

24. Khalil RM, Luz A, Mailhammer R, Moeller J, Mohamed AA, Omran S, et al. Schistosoma mansoni infection in mice augments the capacity for interleukin 3 (IL-3) and IL-9 production and concurrently enlarges progenitor pools for mast cells and granulocytes-macrophages. Infect Immun (1996) 64(12):4960-6.

25. Gómez-García L, López-Marín LM, Saavedra R, Reyes JL, Rodríguez-Sosa M, Terrazas LI. Intact glycans from cestode antigens are involved in innate activation of myeloid suppressor cells. Parasite Immunol (2005) 27(10-11):395-405. doi:10.1111/j.1365-3024.2005.00790.x

26. Allen JE, MacDonald AS. Profound suppression of cellular proliferation mediated by the secretions of nematodes. Parasite Immunol (1998) 20(5):241-7.

27. Loke P, MacDonald AS, Allen JE. Antigen-presenting cells recruited by Brugia malayi induce Th2 differentiation of naïve $\mathrm{CD} 4(+) \mathrm{T}$ cells. Eur J Immunol (2000) 30(4):1127-35. doi:10.1002/(SICI)1521-4141(200004)30:4<1127::AIDIMMU1127>3.0.CO;2-\#

28. Tawill S, Le Goff L, Ali F, Blaxter M, Allen JE. Both free-living and parasitic nematodes induce a characteristic $\mathrm{Th} 2$ response that is dependent on the presence of intact glycans. Infect Immun (2004) 72(1):398-407. doi:10.1128/IAI.72. 1.398-407.2004

29. Saleem SJ, Martin RK, Morales JK, Sturgill JL, Gibb DR, Graham L, et al. Cutting edge: mast cells critically augment myeloid-derived suppressor cell activity. J Immunol (2012) 189(2):511-5. doi:10.4049/jimmunol.1200647

30. Martin RK, Saleem SJ, Folgosa L, Zellner HB, Damle SR, Nguyen GK, et al. Mast cell histamine promotes the immunoregulatory activity of myeloid-derived suppressor cells. J Leukoc Biol (2014). doi:10.1189/jlb.5A1213-644R

31. Yi H, Guo C, Yu X, Zuo D, Wang XY. Mouse CD11b+Gr-1+ myeloid cells can promote Th17 cell differentiation and experimental autoimmune encephalomyelitis. J Immunol (2012) 189(9):4295-304. doi:10.4049/jimmunol. 1200086

32. Mildner A, Mack M, Schmidt H, Brück W, Djukic M, Zabel MD, et al. CCR2+Ly$6 \mathrm{C}$ hi monocytes are crucial for the effector phase of autoimmunity in the central nervous system. Brain (2009) 132(9):2487-500. doi:10.1093/brain/awp144

33. King IL, Dickendesher TL, Segal BM. Circulating Ly-6C+ myeloid precursors migrate to the CNS and play a pathogenic role during autoimmune demyelinating disease. Blood (2009) 113(14):3190-7. doi:10.1182/blood-2008-07-168575

34. Obermajer N, Wong JL, Edwards RP, Chen K, Scott M, Khader S, et al. Induction and stability of human Th17 cells require endogenous NOS2 and cGMPdependent NO signaling. J Exp Med (2013) 210(7):1433-45. doi:10.1084/jem. 20121277

35. Jiao ZJ, Gao JJ, Hua SH, Chen DY, Wang WH, Wang H, et al. Correlation between circulating myeloid-derived suppressor cells and Th17 cells in esophageal cancer. World J Gastroenterol (2012) 18(38):5454-61. doi:10.3748/wjg.v18.i38.5454

36. Yazawa T, Shibata M, Gonda K, Machida T, Suzuki S, Kenjo A, et al. Increased IL17 production correlates with immunosuppression involving myeloid-derived suppressor cells and nutritional impairment in patients with various gastrointestinal cancers. Mol Clin Oncol (2013) 1(4):675-9. doi:10.3892/mco.2013.134

Conflict of Interest Statement: The authors declare that the research was conducted in the absence of any commercial or financial relationships that could be construed as a potential conflict of interest.

Received: 08 May 2014; paper pending published: 02 June 2014; accepted: 15 June 2014; published online: 02 July 2014.

Citation: Manjili MH, Wang X-Y and Abrams S (2014) Evolution of our understanding of myeloid regulatory cells: from MDSCs to Mregs. Front. Immunol. 5:303. doi: 10.3389/fimmu.2014.00303

This article was submitted to Tumor Immunity, a section of the journal Frontiers in Immunology.

Copyright $(2014$ Manjili, Wang and Abrams. This is an open-access article distributed under the terms of the Creative Commons Attribution License (CC BY). The use, distribution or reproduction in other forums is permitted, provided the original author(s) or licensor are credited and that the original publication in this journal is cited, in accordance with accepted academic practice. No use, distribution or reproduction is permitted which does not comply with these terms. 